\title{
Analisis Dampak Pengembangan Wisata Pulau Bokori Terhadap Kondisi Sosial Ekonomi Masyarakat Bajo (Studi Kasus di Desa Mekar Kecamatan Soropia)
}

\author{
Analysis of The Impact of Bokori Island Tourism Development Towards The \\ Bajo Social Economic Conditions \\ (Case Study In The Village Mekar Soropia District)
}

\author{
Samsul Alam Fyka ${ }^{1 *}$, Lukman Yunus², Muhammad Aswar Limi², Awaluddin Hamzah ${ }^{2}$, Darwan ${ }^{2}$ \\ Jurusan Agribisnis, Fakultas Pertanian, Universitas Halu Oleo Jl. H.E.A Mokodompit 9323, Anduonohu \\ Kota Kendari, Indonesia
}

Received: 20 July 2018; Revised: 2 August 2018; Accepted: 6 November 2018

\begin{abstract}
ABSTRAK
Pulau Bokori merupakan salah satu destinasi wisata bahari yang menjadi tempat tujuan pariwisata di Sulawesi Tenggara. Pengembangan Pulau Bokori yang dilakukan pemerintah daerah secara langsung akan memberikan pengaruh bagi masyarakat sekitar. Masyarakat Bajo di Desa Mekar adalah masyarakat yang mendiami daerah sekitar pulau bokori dengan mata pencaharian sebagai nelayan dengan tingkat kemiskinan yang sangat tinggi yakni seluruh masyarakatnya tergolong masyarakat miskin. Keberadaan wisata pulau bokori ini akan memberikan perubahan pada kondisi sosial seperti perubahan gaya hidup dan ekonomi seperti perubahan mata pencaharian, peningkatan pendapatan, perubahan pemilikan asset dan kondisi rumah masyarakat Bajo. Tujuan penelitian ini adalah mengetahui dampak pengembangan wisata pulau Bokori terhadap kondisi sosial dan ekonomi masyarakat Bajo di Desa Mekar. Analisis data yang digunakan di penelitian ini menggunakan metode deskriptif kuantitatif dan kualitatif. Hasil penelitian menunjukkan bahwa pengaruh sosial berupa gaya hidup melalui cara berpakaian masyarakat Bajo akibat adanya wisata Pulau Bokori sangat kecil, yaitu sebesar 10,34 \% saja. Sedangkan gaya hidup melalui cara berkomunikasi dengan menggunakan handphone, terjadi perubahan yaitu sebesar $65,52 \%$. Dampak ekonomi terhadap penambahan mata pencaharian akibat adanya wisata pulau bokori bagi masyarakat Bajo terlibat dalam usaha di sektor wisata, seperti jasa penyeberangan, pedagang kaki lima, penyewaan tikar, penjual makanan sate pokea dan tenaga kerja banana boat. Sehingga terjadi perubahan pendapatan masyarakat dari sector wisata.
\end{abstract}

Kata kunci: dampak wisata; pulau bokori; sosial ekonomi; masyarakat bajo

\begin{abstract}
Bokori Island is one of the maritime tourism destinations that become a tourist destination in Southeast Sulawesi. The development of Bokori Island which is carried out by the regional government will directly influence the surrounding communities. The Bajo community in Mekar Village is a community that inhabits the area around the bokori island with a livelihood as a fisherman with a very high level of poverty, that is, the entire community is classified as poor. The existence of bokori island tourism will provide changes to social conditions such as lifestyle and economic changes such as changes in livelihoods, increased income, changes in asset ownership and the condition of Bajo community housing. The purpose of this study was to determine the impact of developing Bokori island tourism on the social and economic conditions of the Bajo community in Mekar Village. Data analysis used in this study uses descriptive quantitative and qualitative methods. The results showed that the social influence in the form of lifestyle through the Bajo dress as a result of the tourism of Bokori Island was very small, which was only $10.34 \%$. While lifestyle through communication using cellphones, there is a change that is equal to 65.52\%. The economic impact of additional livelihoods due to bokori island tourism for Bajo communities is involved in businesses in the tourism sector, such as crossing services, street vendors, mat rental, satay pokea food sellers and banana boat labor. So there is a change in people's income from the tourism sector.
\end{abstract}

Keywords: tourism impact; bokori island; social economy; bajo community

Available online at HABITAT website: http://www.habitat.ub.ac.id

ISSN: 0853-5167 (p); 2338-2007 (e) 


\section{How to cite:}

Fyka, S. A., Yunus, L., Limi, M. A., \& Hamzah, A. (2018). Analisis Dampak Pengembangan Wisata Pulau Bokori Terhadap Kondisi Sosial Ekonomi Masyarakat Bajo (Studi Kasus di Desa Mekar Kecamatan Soropia). Habitat, 29(3), 106-112. https://doi.org/10.21776/ub.habitat.2018.029.3.13

\section{Pendahuluan}

Pulau Bokori adalah salah satu destinasi wisata yang saat ini sangat berkembang di Sulawesi Tenggara. Pulau yang berada di pinggiran Kota Kendari ini, memiliki nilai sejarah tersendiri bagi masyarakat Bajo. Hal ini, karena Pulau Bokori awalnya berpenghuni masyarakat Bajo dengan mata pencaharian utama sebagai nelayan. Namun, karena pulau itu sering mengalami abrasi, maka pemerintah setempat mengosongkan pulau tersebut dan meminta masyarakat bajo untuk pindah ke pulau lainnya yang terletak tidak jauh dari pulau bokori tersebut. Sebelum adanya pulau bokori sebagai desitnasi wisata, masyarakat Bajo menggantungkan hidup mereka dengan sehari hari bekerja sebagai nelayan. Namun, sejak tahun 2014 pulau bokori dijadikan destinasi wisata bahari oleh pemerintah setempat. Upaya pemerintah dalam mengembangkan pulau Bokori dengan melakukan investasi yang ditujukan untuk pembangunan infrastruktur pendukung pariwisata berupa fasilitas air bersih, listrik, cotage-cotage yang menjadi tempat para wisatawan beristirahat dan gardu panjang menjadikan pulau Bokori menjadi lebih baik dan tempat wisata yang cukup layak untuk di kunjungi. Upaya pembenahan dan strategi promosi yang terus dilakukan oleh pemerintah tersebut membuahkan hasil dengan mulai banyaknya pengunjung yang datang berwisata di tempat tersebut. Jumlah pengunjung di pulau Bokori dari tahun ke tahun dapat dilihat pada Tabel berikut ini:

Tabel 1. Jumlah Pengunjung Wisata di Pulau Bokori, Tahun 2017

\begin{tabular}{cccc}
\hline No & Tahun & $\begin{array}{c}\text { Jumlah Wisatawan } \\
(\text { Org) }\end{array}$ & $\begin{array}{c}\text { Persentase } \\
(\%)\end{array}$ \\
\hline 1 & 2015 & 41.420 & 21,81 \\
2 & 2016 & 54.620 & 28,75 \\
3 & 2017 & 93.916 & 49,44 \\
\hline \multicolumn{2}{c}{ Total } & 189.956 & 100 \\
\hline
\end{tabular}

Sumber : Dinas Pariwisata dan Ekonomi Kreatif Provinsi Sulawesi Tenggara, 2017

*Penulis korespondensi

E-mail : samsulalamfyka@gmail.com

Phone : +6281341840756
Peningkatan jumlah pengunjung membuat masyarakat disekitar kawasan pantai memperoleh kesempatan untuk meningkatkan pendapatan melalui kegiatan usaha yang dilakukan di kawasan seperti kios dan kantin yang menyediakan makanan dan minuman, jasa penyebarangan dan usaha penginapan. Kemudian juga menyewakan fasilitas wisata seperti pondok/gasebo, sarana renang seperti ban, ruang bilas, banana boat dengan harga yang relatif terjangkau. Kondisi ini menjadi bagian dari upaya masyarakat untuk meningkatkan perekonomian dalam bentuk usaha kecil dengan memanfaatkan pengembangan wisata pantai yang dilakukan pemerintah. Karena setiap pengembangan wisata akan mampu memberikan dampak terhadap masyarakat sekitar. Sebagaimana yang diungkap oleh Abdillah, dkk (2016) bahwa dampak tersebut berupa dampak sosial seperti meningkatnya keterampilan penduduk, transformasi mata pencaharian dan transformasi norma. Selain itu dampak budaya yang masih tetap dilestarikan, hal tersebut juga memberikan dampak ekonomi berupa penyerapan tenaga kerja, mendorong aktivitas berwirausaha dan meningkatkan pendapatan masyarakat sekitar

Desa mekar adalah salah satu dari tujuh desa yang termaksud kawasan desa wisata bajo yang ada di kecamatan Soropia Kabupaten Konawe. Desa ini dihuni oleh mayoritas masyarakat bajo dengan jumlah penduduk desa ini sebanyak 136 KK, Menurut Kepala Desa Mekar tingkat ekonomi masyarakat bajo yang ada di Desa Mekar tergolong sangat miskin dengan indikator $95 \%$ penerima bantuan masyarakat miskin, hal ini disebabkan salah satunya karena penghasil rumah tangga mereka hanya bersumber dari nelayan kecil saja.

Perubahan pulau bokori oleh pemerintah setempat dengan menjadikannya sebagai salah satu destinasi wisata andalan di Sulawesi tenggara, mengakibatkan masyarakat setempat memanfaatkan peluang tersebut untuk memperoleh penghasilan tambahan dari keberadaan wisata pulau bokori tersebut. Berkembangnya pariwisata akan memberikan banyak pengaruh bagi masyarakat yang tinggal di lokasi pariwisata itu sendiri. Retnowati (2004) menjelaskan bahwa pariwisata juga berpotensi memicu terjadinya perubahan perilaku 
masyarakat, memudarnya nilai dan norma sosial, kehilangan identitas, konflik sosial, pergeseran mata pencaharian dan pencemaran lingkungan. Berbagai hal tersebut rentan terjadi di masyarakat sebagai akibat dari perkembangan pariwisata. Selain itu juga akan berdampak pada kehidupan ekonomi masyarakat sekitar, yaitu dampak yang positif bagi perkembangan ekonomi masyarakat lokal, diantaranya: penghasilan masyarakat meningkat; meningkatkan peluang kerja dan berusaha; meningkatkan kepemilikan dan kontrol masyarakat lokal; meningkatkanpendapatan pemerintah melalui retribusi wisata. Sedangkan indikasi dampak negatif terhadap ekonomi lokal berupa kenaikan harga barang tidak ditemukan (Hermawan, 2016).

Oleh karena itu, berdasarkan teori terdahulu diatas, maka perlu kiranya adanya penelitian tentang bagaimana kondisi sosial ekonomi masyarakat nelayan bajo di Desa Mekar Kecamatan Soropia sebagai akibat adanya pengembangan disetinasi wisata pulau bokori dilingkungan mereka. Penelitian ini bertujuan untuk mengetahui bagaimana kondisi sosial ekonomi masyarakat nelayan Bajo akibat adanya destinasi wisata pulau Bokori.

\section{Metode Penelitian}

Penelitian ini dilaksanakan di Desa Mekar Kecamatan Soropia Kabupaten Konawe. Pemilihan lokasi penelitian dilakukan secara sengaja (purposive), dengan mempertimbangkan bahwa Desa Mekar adalah mayoritas masyarakatnya adalah masyarakat miskin dengan pekerjaan utama sebagai nelayan kecil. Populasi pada penelitian ini adalah semua masyarakat bajo di Desa Mekar. Penentuan jumlah sampel dilakukan dengan menggunakan rumus berdasarkan Slovin menurut Sugiyono, 2011. Sehingga jumlah sampel dalam penelitian ini adalah 58 orang.

Metode analisis data dalam penelitian ini digunakan untuk menjawab tujuan penelitian, sebagai berikut :

a. Kondisi Sosial dianalisis dengan analisis deskriptif kuantitatif sesuai hasil wawancara dan pengamatan dilapangan untuk menggambarkan bagaimana pengaruh wisata pulau Bokori terhadap perubahan gaya hidup masyarakat Bajo.

b. Kondisi ekonomi dianalisis dengan analisis dekriptif kuantitatif untuk menggambarkan mata pencaharian, penambahan pendapatan dan kepemilikan harta, melalui wawancara kuisioner dengan bentuk penyajian kuantitatif persentase. Analisis pendapatan digunakan untuk menghitung pendapatan masyarakat dari sektor usaha wisata.

\section{Hasil dan Pembahasan}

Pengembangan wisata secara langsung akan memberikan dampak terhadap masyarakat sekitar wisata. Pulau Bokori adalah salah satu objek wisata yang mampu memberikan daya tarik bagi para wisatawan untuk berkunjung rekreasi ke pulau tersebut. Pengembangan pulau bokori yang dilakukan oleh pemerintah dengan merenovasi dan menyiapkan sarana prasarana dalam mendukung kenyaman wisatawan yang berkunjung membuat pengunjung terus mengalami peningkatan yaitu untuk tahun 2017 sebanyak 93.916 orang. Peningkatan pengunjung ini memberikan dampak sosial dan ekonomi bagi masyarakat Bajo.

Kondisi sosial yang dikaji dalam penelitian ini adalah gaya hidup masyarakat bajo. Sedangkan dampak ekonomi yang dikaji dalam penelitian ini adalah mata pencaharian, peningkatan pendapatan, peningkatan kepemilikan asset dan kepemilikan rumah.

\subsection{Dampak Sosial}

Dampak sosial yang diteliti dalam penelitian ini adalah perubahan gaya hidup masyarakat bajo yang diukur melalui perubahan penggunaan komunikasi handphone dan cara berpakaian (Desatria, dkk, 2013). Gaya hidup atau kebiasaan hidup merupakan perilaku seseorang yang ditunjukkan dalam aktivitas khususnya yang berkaitan dengan citra diri untuk merefleksikan status sosialnya.

Masyarakat Bajo memiliki ciri kehidupan tersendiri yang ditandai dengan tempat hidup mereka yang lebih banyak beraktifitas di laut. Sehingga perkembangan - perkembangan informasi dan teknologi jarang untuk diketahui oleh mereka. Namun dengan adanya wisata bahari pulau Bokori akan memberikan pengaruh terhadap gaya hidup mereka. Hal ini karena disebabkan interaksi dengan wisatawan yang datang berkunjung. Interaksi dengan wisatawan secara tidak langsung telah menyebabkan bertambahnya pengetahuan masyarakat bajo mengenai informasi-informasi dari luar. Mantra (1993) yang dikutip oleh Sidarta (2002) menyebutkan bahhwa industri pariwisata akan mempercepat arus perubahan, karena wisatawan yang datang dengan berbagai budaya yang 
berbeda dan lebih lanjut akan berinteraksi dengan masyarakat setempat. Selain itu juga menyebabkan terjadinya akulturasi budaya dan juga proses peniruan budaya dimana seseorang beradaptasi, mengalami dan mempelajari cara hidup di kota. Akhirnya semua aspek kota yang terinternalisasi dalam dirinya melalui suatu proses yang oleh Tarde dalam Marius (2006) dinamakan "imitation process" (proses peniruan). Perubahan struktur, sistem sosial, nilai, sikap dari bergaya lama (gaya desa) menjadi gaya baru (gaya kota) ini merupakan elemen-elemen perubahan sosial kemasyarakatan baik yang dianut secara individual maupun secara bersama-sama dalam suatu sistem sosial.

Perubahan gaya hidup pada masyarakat nelayan yang terjadi antara lain adalah sudah mulai mengenal adanya teknologi komunikasi dan cara berpakaian. Hal ini sebagaimana penelitian yang dilakukan oleh Herdi (2014) dan Indah (2014) yang menyatakan bahwa salah satu bentuk gaya hidup yang mengalami pengaruh akibat adanya wisata adalah pengunaan teknologi dan cara berpakaian. Hal ini juga sejalan dengan penelitian yang telah dilakukan di Desa Mekar bahwa masyarakat bajo sudah banyak yang berkomunikasi dengan menggunakan alat komunikasi yaitu sebanyak 38 responden atau $65,52 \%$. Tata cara komunikasi langsung tatap muka berubah menjadi menggunakan alat komunikasi seperti telepon genggam. Semua responden memiliki telepon genggam yang dapat digunakan untuk berkomunikasi dengan rekanrekannya. Hal tersebut telah mengurangi kebiasaan untuk pertemuan secara langsung dengan tetangga arau keluarga karena kebiasaan tersebut telah mulai digantikan oleh perkembangan teknologi. Selain itu juga dengan adanya pengetahuan masyarakat dalam penggunaan alat komunikasi handphone dapat memperlancar usaha mereka pada sektor wisata. Hal ini sangat dirasakan oleh responden yang bekerja sebagai jasa penyeberangan, karena wisatawan dapat memesan memang jasa penyeberangan melalui handphone pemilik jasa tersebut, hal ini tentu mempermudah dan memperlancar usaha masyarakat.

Cara berpakaian masyarakat tidak memiliki perubahan akibat adanya pengaruh wisata pulau bokori, hal ini dapat dilihat dari Tabel 1 terlihat bahwa hanya 6 responden atau 10,34\% saja yang mengalami perubahan karena sering berinteraksi dengan wisatawan yang datang berkunjung, sedangkan 52 responden tidak mengalami perubahan, hal ini karena menurut mereka bahwa cara berpakaian mereka akibat karena sering menonton televisi, bukan karena terpengaruh dari adanya wisatawan.

Tabel 1. Jumlah Responden menurut Perubahan Gaya Hidup Masyarakat Bajo, Tahun 2017

\begin{tabular}{|c|c|c|c|c|}
\hline \multirow[t]{2}{*}{ No } & \multirow{2}{*}{$\begin{array}{l}\text { Indikator } \\
\text { Gaya Hidup }\end{array}$} & \multicolumn{2}{|c|}{ Jumlah Responden } & \multirow[t]{2}{*}{ Total } \\
\hline & & Berubah & $\begin{array}{l}\text { Tidak } \\
\text { Berubah }\end{array}$ & \\
\hline 1 & $\begin{array}{l}\text { Penggunaan } \\
\text { Teknologi } \\
\text { Komunikasi }\end{array}$ & $\begin{array}{c}38 \\
(65,52 \%)\end{array}$ & $\begin{array}{c}20 \\
(34,48 \%)\end{array}$ & $\begin{array}{c}58 \\
(100 \%)\end{array}$ \\
\hline 2 & $\begin{array}{l}\text { Cara } \\
\text { berpakaian }\end{array}$ & $\begin{array}{c}6 \\
(10,34 \%)\end{array}$ & $\begin{array}{c}52 \\
(89,66 \%)\end{array}$ & $\begin{array}{c}58 \\
(100 \%)\end{array}$ \\
\hline
\end{tabular}

\subsection{Dampak Ekonomi}

Variabel dampak ekonomi dalam penelitian ini adalah mata pencaharian baru, peningkatan pendapatan dan perubahan kepemilikan asset rumah tangga masyarakat Bajo.

\section{a. Mata Pencaharian Baru Masyarakat Bajo \\ Pengembangan wisata pulau Bokori} memberikan dampak ekonomi terhadap kondisi mata pencaharian masyarakat Bajo. Awalnya mata pencaharian utama mereka hanya bersumber sebagai nelayan saja. Namun, dengan adanya pengembangan pulau bokori sebagai destinasi wisata baru yang mampu menyerap wisatawan untuk berkunjung, memberikan pemikiran baru bagi masyarakat Bajo untuk memanfaatkan peluang - peluang usaha baru akibat wisata tersebut. Hiariey et. al (2013) dalam penelitiannya mengungkapkan bahwa keberadaan wisata menyebabkan masyarakat sekitar memanfaatkan kawasan wisata tersebut dengan berbagai macam bentuk usaha pemanfaatan. Kegiatan usaha yang dilakukan tersebut oleh sebagian besar masyarakat sekitar dijadikan sebagai mata pencaharian utama/pokok. Jenis usaha yang dilakukan berdampak positif bagi mereka. Hal tersebut juga diungkap dalam penelitian yang dilakukan oleh Hermawan (2016) bahwa pengembagan desa wisata membawa dampak yang positif bagi perkembangan ekonomi masyarakat lokal di Desa Nglanggeran, diantaranya penghasilan masyarakat meningkat, meningkatkan peluang kerja dan berusaha.

Peluang - peluang ekonomi tersebut dimanfatkan oleh masyarakat Bajo untuk mencari tambahan pendapatan dalam rangka memenuhi 
kebutuhan keluarga. Masyarakat Bajo awalnya menggantungkan hidupnya sebagai nelayan. Pendapatan yang diperoleh hanya berasal dari hasil melaut yang digunakan untuk memenuhi kebutuhan hidup keluarganya dengan cara dijual ke masyarakat lain. Penghasilan nelayan pada saat itu dapat dikatakan pas-pasan karena hanya dapat digunakan untuk memenuhi kebutuhan sandang, pangan, dan papan.

Pengembangan wisata bahari Pulau Bokori memberikan dampak yang positif bagi masyarakat Bajo. Pariwisata diyakini oleh masyarakat dapat memberikan perubahan ke arah yang lebih baik. Penyerapan tenaga kerja akibat adanya pengembangan wisata pulau Bokori terjadi melalui terbukanya unit - unit usaha yang berkaitan dengan wisata. Hal ini sebagai yang dinyatakan oleh Kurniawan (2015) dalam penelitiannya bahwa melalui keberadaan wisata mampu meningkatkan penyerapa tenaga kerja melalui unit -unit usaha yang timbul akibat adanya wisata. Jenis - jenis usaha yang terbentuk yaitu usaha jasa penyeberangan, usaha pedagang kaki lima, usaha penyewaan tikar dan usaha penyewaan banana boat. Keterlibatan masyarakat Bajo dalam usaha - usaha tersebut dapat dilihat melalui tabel berikut ini :

Tabel 2. Jumlah Responden yang terlibat dalam Usaha Wisata Pulau Bokori, Tahun 2017

\begin{tabular}{|c|c|c|c|}
\hline No & $\begin{array}{l}\text { Jenis Unit } \\
\text { Usaha }\end{array}$ & $\begin{array}{l}\text { Jumlah } \\
\text { Responden } \\
\text { (orang) }\end{array}$ & $\begin{array}{c}\text { Persentase } \\
(\%)\end{array}$ \\
\hline 1 & $\begin{array}{l}\text { Jasa } \\
\text { Penyeberangan }\end{array}$ & 7 & 12,07 \\
\hline 2 & $\begin{array}{l}\text { Pedagang Kaki } \\
\text { Lima }\end{array}$ & 25 & 43,10 \\
\hline 3 & $\begin{array}{l}\text { Penyewaan } \\
\text { Tikar }\end{array}$ & 12 & 20,69 \\
\hline 4 & $\begin{array}{l}\text { Penyewaan } \\
\text { Banana Boat }\end{array}$ & 4 & 6,90 \\
\hline 5 & $\begin{array}{l}\text { Penjual } \\
\text { Jajanan Sate } \\
\text { Pokea }\end{array}$ & 10 & 17,24 \\
\hline & Jumlah & 58 & 100 \\
\hline
\end{tabular}

Berdasarkan Tabel 2 di atas, diketahui bahwa semua responden menunjukkan keterlibatan mereka dalam membuka unit - unit usaha melalui adanya wisata pulau bokori tersebut. Hal ini karena banyaknya kunjungan dari wisatawan yang berkunjung ke pulau Bokori. Jenis pekerjaan yang banyak di lakukan oleh masyarakat Bajo yaitu sebagai pedagang kaki lima yaitu sebesar 43,10\%. Hal ini karena pekerjaan yang mudah untuk mereka lakukan, karena masyarakat membuka lapak-lapak penjualan mereka di rumah - rumah mereka sendiri, sehingga mereka lebih mudah untuk mengawasinya. Selain itu juga karena keuntungan yang diperoleh cukup besar di bandingkan dengan pekerjaan - pekerjaan lainnya. Karena mereka menjual dalam dua kondisi, jika hari - hari libur, masyarakat membawa jualanya ke pulau bokori, namun jika hari - hari lainnya mereka berjualan di rumah mereka sendiri. Sedangkan pekerjaan yang paling sedikit keterlibatan masyarakat Bajo adalah penyewaan Banana Boat yaitu 6,90\%, hal ini karena mereka hanya sebagai pekerja saja dan juga banana boat tersebut adalah milik pemerintah. Masyarakat belum ada yang diizinkan untuk mengusahakan sendiri. Jumlah ketersediaan banana boat juga terbatas sehingga keterlibatan masyarakat untuk bekerja juga terbatas.

Berdasarkan hasil penelitian juga diketahui bahwa dengan adanya wisata pulau Bokori, masyarakat Bajo ada yang mengalami perubahan mata pencaharian dan ada juga yang mengalami nafkah ganda. Jenis pekerjaan masyarakat Bajo yang mengalami perubahan dari nelayan berubah menjadi pekerja di jasa penyeberangan wisatawan ke pulau Bokori. Hal ini karena menurut responden bahwa pekerjaan sebagai jasa penyeberangan lebih menguntungkan dari pendapatan, selain itu juga pekerjaan ini juga sangat mudah dilakukan karena jaraknya dekat, sehingga bisa hemat tenaga juga menghemat biaya. Sehingga perahu - perahu mereka untuk melaut mereka alihkan untuk dijadikan sebagai perahu pengangkut wisatawan ke pulau Bokori. Sedangkan jika mereka bekerja sebagai nelayan tangkap, biaya dan tenaga juga sangat besar, selain itu juga hasilnya tidak terlalu memuaskan. Bahkan kadang melaut tidak bisa dilakukan jika keadaan cuaca tidak baik. Sehingga masyarakat yang terlibat dalam unit usaha jasa penyeberangan sudah tidak lagi bekerja sebagai nelayan. Sedangkan masyarakat lain menjadikan pekerjaan yang terkait dengan wisata pulau Bokori itu sebagai pekerjaan tambahan. mereka juga tetap bekerja sebagai nelayan. Alasannya karena pekerjaan di sektor wisata pulau bokori itu hanya dikerjakan saat hari - hari libur saja. Hal ini sesuai dengan apa yang dinyatakan dalam hasil penelitian yang dilakukan oleh Aryani, et., al (2017), bahwa dampak pengembangan wisata 
adalah peningkatan pendapatan yang sangat tinggi tetapi hanya musiman, sehingga pendapatan masyarakat naik turun.

\section{b. Perubahan Tingkat Pendapatan}

Pendapatan masyarakat bajo awalnya hanya bersumber dari hasil nelayan saja. Namun setelah adanya pengembangan pulau bokori sebagai destinasi wisata yang lokasinya sangat berdekatan dengan desa tempat tinggal masyarakat, mempengaruhi cara hidup masyarakat bajo untuk meningkatkan pendapatan mereka dengan memanfaatkan peluang - peluang usaha yang bisa dijadikan sebagai sumber pendapatan baru bagi masyarakat Bajo.

Keterlibatan masyarakat Bajo dalam wisata dengan membuka unit - unit usaha baru bagi penghasilan mereka, akan memberikan dampak bagi peningkatan pendapatan, hal ini karena munculnya pekerjaan - pekerjan tambahan atau baru bagi masyarakat Bajo untuk memenuhi kebutuhan hidup mereka. Pendapatan rata - rata yang diperoleh masyarakat Bajo melalui keterlibatan mereka pada wisata bahari Pulau Bokori di golongkan berdasarkan Berdasarkan penggolongan menurut Badan Pusat Statistik (BPS, 2014) membedakan menjadi 4 golongan yaitu golongan pendapatan sangat tinggi pendapatan rata-rata lebih dari Rp. 3.500.000,00 per bulan. Golongan pendapatan tinggi jika pendapatan rata-rata antara Rp.2.500.000,00 Rp. 3.500.000,00. Golongan pendapatan sedang jika pendapatan rata -rata antara Rp. 1.500 .000 Rp. 2.500.000,00 per bulan, dan golongan pendapatan rendah kurang dari Rp. 1.500.000,00. Untuk lebih jelasnya dapat dilihat pada Tabel 3 berikut ini.

Tabel 3. Jumlah dan Persentase Perubahan Pendapatan Masyarakat Bajo dari Sektor Wisata Pulau Bokori, Tahun 2017

\begin{tabular}{ccccccc}
\hline \multirow{2}{*}{ No. } & $\begin{array}{c}\text { Tingkat Pendapatan } \\
(\text { Rp/Bulan) }\end{array}$ & \multicolumn{2}{c}{ Sebelum } & \multicolumn{2}{c}{ Sesudah } & $\begin{array}{c}\text { Perubahan } \\
(\%)\end{array}$ \\
\cline { 3 - 6 } & & $\begin{array}{c}\text { Jumlah } \\
(\text { Org })\end{array}$ & $\begin{array}{c}\text { Persentase } \\
(\%)\end{array}$ & $\begin{array}{c}\text { Jumlah } \\
(\text { Org })\end{array}$ & $\begin{array}{c}\text { Persentase } \\
(\%)\end{array}$ & \\
\hline 1 & Rendah & 30 & 51,72 & 14 & 24,14 & 27,58 \\
2 & Sedang & 23 & 39,66 & 28 & 48,27 & 8,61 \\
3 & Tinggi & 5 & 8,62 & 11 & 18,97 & 27,59 \\
4 & Sangat Tinggi & 0 & 0 & 5 & 8,62 & 8,62 \\
\hline & Jumlah & 58 & 100 & 58 & 100 & \\
\hline
\end{tabular}

Berdasarkan Tabel 3 nampak bahwa sebelum adanya pengembangan wisata pulau Bokori di kecamatan soropia, kondisi pendapatan masyarakat desa mekar hampir semua tergolong dengan tingkat pendapatan rendah sebesar 51,72 $\%$ (30 responden). Hal ini lebih disebabkan karena sumber-sumber pendapatan masyarakat yang masih sangat terbatas, mereka masih menggantungkan hidupnya melalui mata pencaharian nelayan kecil. Namun, setelah adanya pengembangan wisata pulau Bokori menunjukkan adanya perubahan pendapatan masyarakat yang tergolong rendah yakni menjadi hanya $24,14 \%$ (14 responden). Perubahan ini ditunjukkan dengan adanya penurunan masyarakat bajo di Desa Mekar yang tergolong pendapatan rendah atau dengan kata lain masyarakat yang berpenghasilan rendah mengalami pengurangan sejak adanya wisata pulau Bokori. Sehingga, dapat dikatakan bahwa keberadaan wisata pulau Bokori mampu meningkatan penghasilan bagi masyarakat Bajo yang berpenghasilan rendah melalui unit- unit usaha yang mereka lakukan. Hal ini sesuai dengan hasil penelitian yang dilakukan oleh Martina (2016) yang menyatakan bahwa kegiatan pariwisata di Taman Wisata Kawah Puth berpengaruh positif dilihat dari segi ekonomi dapat meningkatkan pendapatan masyarakat setempat.

Begitu pula dengan masyarakat Bajo yang awalnya berpenghasilan sedang, tinggi dan sangat tinggi sebelum adanya wisata pulau Bokori mengalami perubahan berubah peningkatan pendapatan mereka, yaitu masing - masing sedang sebesar $8,61 \%$, tinggi $27,59 \%$ dan sangat tinggi $8,62 \%$. Hal ini membuktikan bahwa keberadaan wisata pulau Bokori mampu meningkatkan perekonomian masyarakat bajo di Desa Mekar dalam meningkatkan kualitas hidup mereka. Hal ini sejalan dengan penelitian yang dilakukan oleh Hijriati et, al (2014) yang menyatakan bahwa dengan adanya ekowisata berbasis masyarakat Batusuhunan memberikan perubahan bagi masyarakat terutama dalam aspek ekologi, sosial dan ekonomi bagi masyarakat melalui terbukanya kesempatan bekerja dengan unit - unit usaha yang dapat menjadi pendapatan 
tambahan bagi masyarakat setempat. Begitupula dengan penelitian yang dilakukan oleh Dritasto et,al (2013) menunjukkan bahwa dengan adanya wiisata bahari akan memberikan dampak ekonomi terhadap pendapatan masyarakat di Pulau Tidung.

\section{Kesimpulan}

Berdasarkan hasil pembahasan di atas, maka kesimpulan dari penelitian ini adalah :

1. Pengaruh sosial keberadaan wisata pulau bokori bagi masyarakat bajo di Desa Mekar adanya perubahan terhadap gaya hidup melalui cara berpakaian dan cara berkomunikasi.

2. Pengaruh ekonomi keberadaan wisata pulau bokori bagi masyarakat bajo di Desa Mekar adalah adanya perubahan mata pencaharian baru dan juga peningkatan pendapatan masyarakat melalui sector wisata.

\section{Daftar Pustaka}

Abdillah A.B.Y., Hamid, D. 2016. Dampak Pengembangan Pariwisata terhadap Kehidupan Masyarakat Lokal di Kawasan Wisata (Studi pada Masyarakat sekitar Wisata Wendit, Kabupaten Malang). Jurnal Administrasi Bisnis, Vol 30 (1). Hal 74 78.

Aryani SW, Sunarti, Darmawan A. 2017. Analisis Dampak Pembangunan Pariwisata Pada Aspek Ekonomi dan Sosial Budaya Masyarakat (Studi Kasus pada Desa Wisata Bejiharjo, Kecamatan Karangmojo, Kabupaten Gunungkidul, D.I. Yogyakarta). Jurnal Administrasi Bisnis. Vol. 49 (2). Hal :142-146.

Desatria L, Fachrina, Yasin, F. 2013. Dampak sosial ekonomi objek wisatathe unique park waterboomdi kotasawahlunto. Jurnal Ilmu Sosial Mamangan, Vol II (2). Hal : 82 -91 .

Dritasto A, Anggraeni AA. 2013. Analisis Dampak Ekonomi Wisata Bahari Terhadap Pendapatan Masyarakat Di Pulau Tidung. Jurnal Online Institut Teknologi Nasional. XX (X). Malang (ID) : Institut Teknologi Nasional. Hal 1-8. Dapat diunduh dari :http://portalgaruda.org/download_article.p hp? article $=57445$.
Hijriati, Emma. et. al. 2014. Pengaruh Ekowisata Berbasis Masyarakat terhadap Perubahan Kondisi Ekologi, Sosial dan Ekonomi di Kampung Batusuhunan, Sukabumi. Sodality : Jurnal Sosiologi Pedesaan. Vol 2 (3). Hal $146-159$.

Hermawan, H. 2016. Dampak Pengembangan Desa Wisata Nglanggeran Terhadap Ekonomi Masyarakat Lokal. Jurnal Pariwisata, Vol III. No.2. Hal 105 - 117.

Hiariey SL, Sahusilawane W. 2013. Dampak Pariwisata terhadap Pendapatan dan Tingkat Kesejahteraan Pelaku Usaha di Kawasan Wisata Pantai Natsepa, Pulau Ambon. Jurnal Organisasi dan Manajemen, Vol 9, No. 1. Hal 87 - 105.

Kurniawan, W. 2015. Dampak Sosial Ekonomi Pembangunan Pariwisata Umbul Sidomukti Kecamatan Bandungan Kabupaten Semarang. Economics Development Analysis Journal. Vol 4(4). Hal 443-451.

Martina, S. 2016. Dampak Pengelolaan Taman Wisata Alam Kawah Puth terhadap Kehidupan Sosial dan Ekonomi Masyarakat. Jurnal Pariwisata. Vol 1(2). Hal $81-88$.

Sugiyono, 2011. Metode Penelitian Kuantitatf Kualitatif dan R\&D. Badung: Alfabeta. 